ACTA UNIVERSITATIS LODZIENSIS

FOLIA LITTERARIA POLONICA 2(32) 2016

http://dx.doi.org/10.18778/1505-9057.32.13

Bartłomiej Secler*, Agnieszka Stępińska**, Ewa Jurga-Wosik ${ }^{* * *}$, Dominika Narożna $^{* * * *}$, Kinga Adamczewska ${ }^{* * * * *}$

\title{
Model dziennikarstwa zorientowany na obywateli w perspektywie paradygmatu społecznej odpowiedzialności mediów. Przykład prasy w Polsce
}

\section{Paradygmat społecznej odpowiedzialności mediów}

Wraz z ewolucją i rozwojem mediów zmieniały się ich role i funkcje, które pełniły one w społeczeństwie. Harold Lasswell wskazywał po wojnie na trzy podstawowe funkcje komunikowania w społeczeństwie, tj. nadzór nad otoczeniem, koordynację elementów systemu społecznego, transmisję kultury'. Z kolei Paul Lazarsfeld i Robert K. Merton zwracali uwagę na następujące funkcje mediów masowych: nadawanie statusu społecznego osobom i znaczenia informacjom, wzmacnianie norm społecznych, pełnienie funkcji rzecznika publicznej moralności, wywoływanie dyskusji i zmuszanie jednostek do samookreślania się².

Media szybko stały się skutecznym narzędziem mobilizacji i pobudzania innowacyjności ludzi (także w odniesieniu do podejmowania przez nich decyzji mających na celu wdrażanie rozwiązań usprawniających codzienne życie), są dziś - jak nigdy dotąd - dominującym źródłem obrazów i definicji rzeczywistości społecznej. Nadto tworzą, jak również gromadzą i publicznie przedstawiają

* Dr, e-mail:bartlomiej.secler@amu.edu.pl; **Prof. UAM dr hab., e-mail: agnieszka.stepinska@amu.edu.pl; ***Dr, e-mail: ewa.jurga-wosik@amu.edu.pl; ****Dr, e-mail: dominika.narozna@amu.edu.pl; *****Mgr, e-mail: kinga.adamczewska@amu.edu.pl; Uniwersytet im. Adama Mickiewicza w Poznaniu, Wydział Nauk Politycznych i Dziennikarstwa, ul. Umultowska 89a, 61-614 Poznań.

${ }^{1}$ T. Goban-Klas, Media i komunikowanie masowe. Teorie i analizy prasy, radia, telewizji i Internetu, Wydawnictwo Naukowe PWN, Warszawa 2008, s. 123. Por. H. Lasswell, The Structure and Function of Communication in Society, [in:] The Communication of Ideas, ed. L. Bryson, Harper, New York 1948, pp. 32-51.

${ }^{2}$ M. Nieć, Komunikowanie społeczne i media. Perspektywa politologiczna, Wolters Kluwer Polska Sp. z o.o., Warszawa 2010, s. 80. Por. P. Lazarsfeld, R. Merton, Mass Communication, Popular Taste, and Organized Social Action, [in:] The Communication of Ideas, pp. 32-51. 
różnorodne wartości kulturowe i społeczne. Dość wspomnieć także o ich udziale w procesach demokratyzacji. Wojciech Stankiewicz wyraża słuszny pogląd, że zadaniem mediów nie jest już tylko upowszechnienie informacji o aktualnych wydarzeniach. Media funkcjonujące w modelu demokracji liberalnej pełnią ważne funkcje społeczne, czego przejawem jest chociażby piastowanie przez nie roli pośrednika pomiędzy obywatelem a władzą ${ }^{3}$.

Celem niniejszego artykułu jest zaprezentowanie relacji pomiędzy obywatelami a mediami, w szczególności modelu służby obywatelskiej, który w tytule niniejszego tekstu został określony jako „model dziennikarstwa zorientowany na obywateli". Tłem teoretycznym dla tego modelu jest paradygmat społecznej odpowiedzialności mediów.

Studia nad rolami i funkcjami mediów masowych dowodzą nie tylko ich wpływu na społeczeństwo, ale także wartościują ten wpływ, zwracając uwagę na jego charakter - pozytywny bądź negatywny. Jak odnotowuje Krzysztof R. Nowakowski, „stwierdzenie tego faktu dało początek teorii odpowiedzialności społecznej”», której źródłem był raport Social Responsibility Theory of the Press opublikowany w 1947 roku przez amerykańską prywatną komisję badawczą do spraw wolności prasy. Powstała ona kilka lat wcześniej w odpowiedzi na szeroką krytykę prasy amerykańskiej, której zarzucano komercjalizację, pogoń za sensacją, brak równowagi politycznej oraz zapędy monopolistyczne ${ }^{5}$. W dokumencie tym posługiwano się pojęciem odpowiedzialności społecznej i wskazano na podstawowe standardy dziennikarskie. Podkreślono również, że „społecznie odpowiedzialna prasa" powinna prezentować pełny obraz wydarzeń danego dnia, nadto zaś, powinna być forum wyrażania komentarzy i krytyki oraz stanowić nośnik publicznego wyrazu opinii. W myśl zaleceń prasa powinna reprezentować opinie wszystkich grup, które tworzą społeczeństwo, przy jednoczesnym uwzględnieniu celów i wartości społecznych ${ }^{6}$.

Analizując normatywną społeczną teorię mediów, Denis McQuail wyróżnia pięć podstawowych elementów konstruujących paradygmat odpowiedzialności społecznej. W pierwszej kolejności badacz wskazuje na obowiązki mediów, które mają one względem społeczeństwa. W tym kontekście zwraca uwagę na własność mediów jako dobro powierzone ich posiadaczom przez społeczeństwo. Po drugie, media - przede wszystkim informacyjne - powinny charakteryzować się określonym

${ }^{3}$ W. Stankiewicz, Media a demokracja w społeczeństwie informacyjnym, [w:] Teoria i praktyka funkcjonowania mediów, red. J. Marszałek-Kawa, Wydawnictwo Adam Marszałek, Toruń 2010, s. 48-49.

${ }^{4}$ K.R. Nowakowski, Społeczna odpowiedzialność mediów w systemie gospodarki wolnorynkowej, Szkoła Wyższa im. Bogdana Jańskiego, Warszawa 2009, s. 5.

${ }^{5}$ D. McQuail, Teoria komunikowania masowego, tłum. M. Bucholc, A. Szulżycka, Wydawnictwo Naukowe PWN, Warszawa 2008, s. 183.

${ }^{6}$ Tamże, s. 184. 
systemem wartości, na który składają się: prawdomówność, rzetelność, uczciwość czy obiektywizm. Trzecim elementem tworzącym „Social Responsibility Theory” jest wolność mediów, aczkolwiek podlegająca samoregulacji. Chodzi tu głównie o postulat wolności słowa oraz swobodę pracy dziennikarskiej. Kolejny imperatyw stanowi konieczność przestrzegania ustalonych kodeksów etyki i dobrych praktyk zawodowych. Ostatnią zasadą tworzącą paradygmat jest pogląd - wprost wyrażony przez McQuaila - że w określonych okolicznościach rząd może być zobowiązany do interwencji w działania mediów, szczególnie gdy w grę wchodzi ochrona interesu publicznego lub pojawia się sytuacja zagrożenia dla ładu społecznego7.

Paradygmat odpowiedzialności społecznej przedstawia media jako element systemu społecznego, którego zasadniczym wymogiem jest respektowanie norm współżycia grupowego przyjętego w społeczeństwie. Warto także odnotować, że czynnikiem sprzyjającym wzmacnianiu społecznej odpowiedzialności mediów może być profesjonalizacja dziennikarstwa oraz wrażliwość samych dziennikarzy na problemy związane z etyką wykonywanego przez nich zawodu, szczególnie w zakresie jakości tworzonych przez nich materiałów ${ }^{8}$. Pełnione przez dziennikarzy role dotyczą nie tylko określonych umiejętności, ale także - a może przede wszystkim - spełnienia oczekiwań społecznych związanych z misją wykonywania zawodu zaufania publicznego?.

Możliwość wyrażenia swojej opinii jest kwestią kluczową w systemie demokratycznym opartym o wolne media i dziennikarzy rzetelnie informujących o sprawach istotnych z punktu widzenia (interesu) społeczeństwa. Pogląd o kluczowym znaczeniu dobrze poinformowanej opinii publicznej w demokracji nie jest przesadzony. Sytuacja jednak komplikuje się, gdy rzeczywistość miesza się ze światem gazetowej czy ekranowej fikcji lub intencjonalnie wykreowanych obrazów. Ryszard Kapuściński stwierdził, że „zmorą komunizmu był brak informacji, zmorą demokracji ery technologicznej - przesyt informacją"10. Nie ulega wątpliwości, że postępujący chaos informacyjny, pogoń za newsem, ekonomika mediów, konkurencja na rynku mediów, tabloidyzacja (już nie tylko prasy) mają istotny wpływ na charakter dziennikarstwa zorientowanego na obywateli, w którym ważną rolę zajmuje społeczna odpowiedzialność mediów. Relacje te są jednak bardzo złożone. Rozważając na przykład wzajemne powiązania świata polityki i mediów (w tym dziennikarzy), szybko zauważymy, że z jednej strony, środki przekazu dostarczają informacji na temat poczynań władzy i prezentują

7 Tamże, s. 185.

${ }^{8}$ Szerzej na temat profesjonalizacji w dziennikarstwie: T. Kononiuk, Profesjonalizacja $w$ dziennikarstwie. Między modernizmem a ponowoczesnościa, Oficyna Wydawnicza ASPRA-JR, Warszawa 2013.

9 J. Jęczeń, K. Zielińska-Król, Koncepcja odpowiedzialności mass mediów w myśli Denisa McQuaila, „Roczniki Nauk o Rodzinie i Pracy Socjalnej” 2012, nr 4, s. 293.

${ }^{10}$ R. Kapuściński, Dwa światy, „Newsweek Polska” 2001, nr 16-17, s. 166. 
poglądy zgodne z własną oceną (oddając niekiedy głos obywatelom, choć i tak spotykają się z zarzutem, że czynią to wybiórczo), z drugiej zaś strony, te same media udostępniają władzy swoje łamy i serwisy, by ta mogła się bezpośrednio zwracać do obywateli. Warto podkreślić, że włączenie polityki i procesów z niej wynikających $\mathrm{w}$ sferę mediów może prowadzić do niebezpiecznego - zarówno z punktu widzenia obywatela, jak i władzy - upraszczania politycznych przekazów. Konsekwencją takiego działania może być z kolei traktowanie określonych treści politycznych jako wypaczonych, kłamliwych, mało istotnych lub nierealnych, co może prowadzić do istotnej zmiany rzeczywistego obrazu polityków i polityki w świadomości społecznej, a nadto do odejścia od zasad paradygmatu społecznej odpowiedzialności mediów ${ }^{11}$.

\section{Modele dziennikarstwa}

Podstawą do wielu rozważań nad postawą dziennikarzy względem aktorów politycznych w warunkach demokracji jest podział zaproponowany przez Hugha M. Culbertsona, który wyróżnił postawę: 1) tradycyjną (neutralną), sprowadzającą się do rzetelnego i szybkiego informowania o wydarzeniach; 2) interpretacyjną, polegającą na wyjaśnianiu opisywanych zdarzeń i zjawisk z uwzględnieniem społecznego, historycznego kontekstu i ukazaniem potencjalnych konsekwencji prezentowanych zdarzeń i zjawisk, oraz 3) aktywną, która obejmuje nie tylko relacjonowanie zdarzeń i zjawisk, ale także wskazywanie rozwiązań społecznych problemów ${ }^{12}$.

To właśnie w oparciu o ten podział David H. Weaver i G. Cleaveland Wilhoit zaproponowali podział na cztery role mediów: 1) rozpowszechnianie informacji tak szybko, jak jest to możliwe z zachowaniem dbałości o weryfikację informacji; 2) bieżące analizowanie i interpretowanie wydarzeń politycznych; 3) kwestionowanie wybranych działań podejmowanych przez elity polityczne i ekonomiczne; 4) dostarczanie odbiorcom tego, czego oczekują, w tym rozrywki, oraz mobilizowanie społeczeństwa do działania i wyrażania przez nie opinii. Typologia ta stanowiła punkt wyjścia do skonstruowania pytań, które znalazły się w ankietach wykorzystanych w badaniach kierowanych przez Weavera (zarówno w USA, jak i w międzynarodowych badaniach porównawczych) ${ }^{13}$.

${ }^{11}$ B. Secler, Polityka i media w obliczu demokracji medialnej, [w:] Demokracja w obliczu nowych mediów. Elektroniczna demokracja, wybory przez Internet, kampania w sieci, red. M. Musiał-Karg, Wydawnictwo Adam Marszałek, Torun 2013, wszędzie.

${ }^{12}$ H. Culbertson, Three perspectives in American journalism, „Journalism Monographs” 1983, No. 83, pp. 1-33.

${ }^{13}$ D.H. Weaver, G.C. Wilhoit, The American Journalist in the 1990s. U.S. News People at the End of an Era, Lawrence Erlbaum Asssociaties, Mahwah NJ 1996. W Polsce badania ankietowe 
Późniejsze badania empiryczne i rozważania teoretyczne nad tzw. kulturami dziennikarstwa pozwoliły na doprecyzowanie wymiaru kultury dziennikarskiej oraz rozpoznania trzech głównych typów faktycznej aktywności dziennikarzy (role perfomance), $\mathrm{tj}$. interwencjonizmu, dystansu wobec władzy oraz orientacji rynkowej. Poprzez połączenie wcześniej wyróżnionych ról (na bazie teorii normatywnych) z typami aktywności Thomas Hanitzsch skonstruował wielowymiarową typologię funkcji mediów oraz postaw dziennikarzy wobec aktorów politycznych ${ }^{14}$.

Składają się na nią następujące modele dziennikarstwa: 1) zdystansowany „pies stróżujący” (detached watchdog), który koncentruje się na dostarczaniu informacji politycznych obywatelom, zachowując duży dystans wobec władzy; charakteryzuje się sceptycyzmem oraz krytycznym podejściem do elity politycznej; 2) populistyczny dostawca informacji (populist disseminator) skoncentrowany na oczekiwaniach odbiorców i zaspokajaniu ich potrzeby otrzymywania interesujących informacji bez angażowania się w procesy polityczne i społeczne; 3) krytyczny czynnik zmiany (critical change agent), który przyjmuje krytyczną postawę wobec elity politycznej, nawołuje i zachęca do przeprowadzenia zmian społecznych, wskazuje problemy i ich rozwiązania oraz wpływa na postrzeganie spraw (wysoki poziom interwencjonizmu połączony z dużym dystansem wobec ośrodka władzy); 4) oportunistyczna podpora (opportunist facilitator) ośrodka władzy, wspierająca elity polityczne i ich politykę.

Z kolei Claudia Mellado zaproponowała model ról dziennikarskich zbudowany wokół trzech głównych wymiarów pracy dziennikarzy: 1) relacje z aktorami politycznymi (przede wszystkim sprawującymi władze); 2) zaangażowanie $\mathrm{w}$ życie publiczne; 3) relacje $\mathrm{z}$ odbiorcami ${ }^{15}$. Relacje dziennikarzy $\mathrm{z}$ władzą oparte są w tym ujęciu na dychotomicznym podziale „psa stróżującego” (watchdog) i „lojalnego pomocnika” (loyal-facilitator). Pierwszy zajmuje się krytyką, kwestionowaniem oraz ukazywaniem i nagłaśnianiem nieprawidłowości, drugi zaś przybiera postawę lojalną wobec ośrodka władzy lub wobec kraju (narodu). Cechą charakterystyczną postawy lojalnej wobec elit politycznych jest przede wszystkim współpraca i wspieranie władzy, np. w zakresie realizowanej przez nią polityki, budowania jej pozytywnego wizerunku, utrzymania dotychczasowej pozycji.

wśród dziennikarzy w oparciu o ten model prowadzili m.in. Jerzy Olędzki, Agnieszka Stępińska i Szymon Ossowski oraz Bogusława Dobek-Ostrowska z zespołem. Więcej o tych badaniach m.in. w: A. Stępińska, S. Ossowski, Dziennikarze w Polsce. Wartości, priorytety i standardy zawodowe, „Studia Medioznawcze” 2011, nr 1, s. 17-30; B. Dobek-Ostrowska, P. Barczyszyn, A. Michel, Zmiana w dziennikarstwie. Kultura zawodowa polskich dziennikarzy (badania ilościowe), „Studia Medioznawcze" 2013, nr 1, s. 11-28.

${ }^{14}$ T. Hanitzsch, Deconstructing Journalism Culture. Toward a Universal Theory, „Communication Theory" 2007, No. 4, pp. 367-385.

${ }^{15}$ C. Mellado, Professional roles in news content: Six dimensions of journalistic role performance, „Journalism Studies” 2015, No. 4, pp. 596-614. 
Lojalność wobec kraju przejawia się natomiast w budowaniu wspólnoty, z zaakcentowaniem ważnych z punktu widzenia ogółu wartości, wskazywaniu i promowaniu osiągnięć narodu oraz budowaniu pozytywnego wizerunku państwa.

Drugi wymiar pracy dziennikarskiej określony w modelu Mellado uwzględnia dwie skrajne postawy. $Z$ jednej strony jest to pasywność - rozumiana jako dystans wobec opisywanych wydarzeń, problemów czy zjawisk i wyłącznie rozpowszechnianie informacji o nich, zaś z drugiej - badaczka wskazuje na interwencjonizm, który jest aktywną postawą dziennikarzy, tj. prezentują oni własne opinie i poglądy, formułują oceny, reprezentują jedną ze stron. Relacje mediów $\mathrm{z}$ odbiorcami, a zatem trzeci element modelu Mellado, obejmują trzy modele dziennikarstwa. Pierwszy, usługowy model (service) obejmuje rady, porady, informacje na temat wydarzeń, które mogą mieć istotny wpływ na codzienne życie ludzi. Model rozrywkowy (infotainment) sprowadza się, w ujęciu zaproponowanym przez Mellado, do opisu prywatnego życia jednostek, np. aktorów politycznych, skandali, emocji, sensacji itp. Z kolei model służby obywatelskiej (civic), będący modelem dziennikarstwa zorientowanym na obywateli, polega przede wszystkim na prezentowaniu właśnie ich perspektywy, ich żądań, pytań, działań, ale także edukacji obywatelskiej i zachęcaniu ludzi do udziału w życiu publicznym $^{16}$.

\section{Dziennikarstwo zorientowane na obywateli - analiza zawartości wybranych tytułów prasowych}

W tej części artykułu zostaną zaprezentowane wyniki badań uzyskane w drodze realizacji międzynarodowego projektu „Journalistic Role Performance Around the Globe" 17 opartego na modelu ról dziennikarskich Mellado. Podstawą eksploracji była przygotowana na potrzeby projektu książka kodowa, która służyła do ilościowej analizy zawartości przekazów medialnych. Nadrzędnym celem wykorzystania tego narzędzia było określenie ról mediów (funkcji dziennikarzy), które faktycznie pełnione są przez pracowników mediów. W niniejszej pracy zaprezentowane zostaną dane dotyczące wskaźników odzwierciedla-

\footnotetext{
16 Tamże, s. 602.

${ }^{17}$ Celem tego naukowego przedsięwzięcia, kierowanego przez Claudię Mellado z Pontificia Universidad Catolica de Valparaiso w Chile, jest przeprowadzenie międzynarodowych badań porównawczych zarówno nad postrzeganiem funkcji mediów i ról dziennikarzy (badanie ankietowe wśród dziennikarzy), jak i nad ich faktycznym pełnieniem (analiza zawartości przekazów medialnych). Odrębna uwaga w tym projekcie poświęcona została także potencjalnym adeptom dziennikarstwa (badanie ankietowe wśród studentów kierunku dziennikarstwo i komunikacja społeczna). Projekt realizowany jest od 2013 r. Więcej o projekcie: www.journaliticperformance.org.
} 
jących postawy dziennikarzy wobec odbiorców przypisanych modelowi służby obywatelskiej.

Weryfikację modelu podporządkowano następującym pytaniom zawartym w książce kodowej: (1) Czy w materiale dziennikarskim została zaprezentowana perspektywa obywateli? (2) Czy w materiale zaprezentowane zostały żądania obywateli pod adresem władzy? (3) Czy dziennikarz swoją opinią wspiera w materiale żądania obywateli? (4) Czy materiał ma wpływ na społeczność lokalną? (5) Czy materiał dostarcza wiedzy o obowiązkach i prawach obywateli? (6) Czy materiał dostarcza obywatelom dodatkowych informacji potrzebnych np. do podjęcia określonej decyzji lub działań politycznych? (7) Czy materiał zawiera pytania od obywateli pod adresem władzy? (8) Czy materiał informuje o działaniach podejmowanych przez obywateli, np. protesty uliczne? (9) Czy w materiale wyrażono poparcie dla działań obywateli?

Analizie poddano zawartość czterech tytułów prasowych: „Gazety Wyborczej”, „Rzeczpospolitej”, „Faktu”, „Naszego Dziennika”. Zostały one wybrane w oparciu o następujące kryteria: typ prasy, poziom czytelnictwa oraz orientacja polityczna. Materiał badawczy pochodzi z lat 2012-2013. Łącznie analizie poddano 1130 artykułów prasowych. Dane w tabelach obejmują liczbę artykułów poddanych analizie (częstość) przynależnych poszczególnym tytułom prasowym oraz procentowo określony wynik odpowiedzi na pytanie zawarte w książce kodowej w stosunku do analizy zawartości każdego objętego badaniem artykułu prasowego.

Perspektywa obywateli. W tej kategorii położono nacisk na określenie, czy materiał prasowy prezentuje perspektywę obywateli na dany problem lub wydarzenia, którym poświęcony był tekst dziennikarski. Zwrócono też uwagę, czy obywatele zaprezentowali swoje poglądy, oceny, reakcje na działania lub decyzje określonych podmiotów (np. podmiotów politycznych). Opinie takie mogły być wyrażone w tekście w postaci cytatów wypowiedzi obywateli lub relacji dziennikarza. Szczegółowe wyniki prezentuje Tabela 1. 
Tabela 1. Perspektywa obywateli

\begin{tabular}{|c|c|c|c|}
\hline Tytuł prasowy & Odpowiedź & $\begin{array}{c}\text { Częstość } \\
\text { (w liczbach) }\end{array}$ & $\begin{array}{c}\text { Procent odpowiedzi } \\
(\%)\end{array}$ \\
\hline \multirow{3}{*}{$\begin{array}{c}\text { „Gazeta } \\
\text { Wyborcza" }\end{array}$} & $\mathrm{Nie}$ & 283 & 82,5 \\
\hline & Tak & 60 & 17,5 \\
\hline & Ogółem & 343 & 100,0 \\
\hline \multirow{3}{*}{ „Rzeczpospolita” } & Nie & 217 & 85,1 \\
\hline & Tak & 38 & 14,9 \\
\hline & Ogółem & 255 & 100,0 \\
\hline \multirow{3}{*}{ „Fakt” } & Nie & 283 & 93,4 \\
\hline & Tak & 20 & 6,6 \\
\hline & Ogółem & 303 & 100,0 \\
\hline \multirow{3}{*}{ „Nasz Dziennik” } & Nie & 151 & 65,7 \\
\hline & Tak & 79 & 34,3 \\
\hline & Ogółem & 230 & 100,0 \\
\hline
\end{tabular}

Źródło: oprac. własne. Projekt „Journalistic Role Performance Around the Globe”.

Najczęściej perspektywa obywateli na problem opisywany przez dziennikarzy była prezentowana na łamach katolickiego „Naszego Dziennika”, najrzadziej zaś w tytule tabloidowym „Fakt”, który bardzo często podejmuje na swoich łamach kwestie społeczne, niejako stojąc po stronie obywateli i działając w ich imieniu. Dziennik ten wyprzedziły także „Gazeta Wyborcza” i „Rzeczpospolita” - między tymi gazetami różnica w prezentowaniu perspektywy obywateli jest niewielka, choć ze wskazaniem na pierwszy z wymienionych tytułów.

Żądania obywateli. Poprzez analizę zawartości próbowano odpowiedzieć na pytanie, który z analizowanych tytułów i w jakim stopniu prezentuje na swoich łamach żądania lub propozycje formułowane przez obywateli pod adresem ośrodków władzy. Podobnie jak przy poprzedniej kategorii, mogły być one wyartykułowane w materiale wprost (w postaci cytatów wypowiedzi obywateli) lub w relacji dziennikarza. Wyniki dla tej kategorii zostały zawarte w Tabeli 2. 
Tabela 2. Żądania obywateli

\begin{tabular}{|c|c|c|c|}
\hline Tytuł prasowy & Odpowiedź & $\begin{array}{c}\text { Częstość } \\
\text { (w liczbach) }\end{array}$ & $\begin{array}{c}\text { Procent odpowiedzi } \\
(\%)\end{array}$ \\
\hline \multirow{3}{*}{$\begin{array}{c}\text { „Gazeta } \\
\text { Wyborcza" }\end{array}$} & $\mathrm{Nie}$ & 313 & 91,3 \\
\hline & Tak & 30 & 8,7 \\
\hline & Ogółem & 343 & 100,0 \\
\hline \multirow{3}{*}{ „Rzeczpospolita” } & Nie & 245 & 96,1 \\
\hline & Tak & 10 & 3,9 \\
\hline & Ogółem & 255 & 100,0 \\
\hline \multirow{3}{*}{ „Fakt” } & Nie & 296 & 97,7 \\
\hline & Tak & 7 & 2,3 \\
\hline & Ogółem & 303 & 100,0 \\
\hline \multirow{3}{*}{ „Nasz Dziennik” } & Nie & 186 & 80,9 \\
\hline & Tak & 44 & 19,1 \\
\hline & Ogółem & 230 & 100,0 \\
\hline
\end{tabular}

Źródło: oprac. własne. Projekt „Journalistic Role Performance Around the Globe”.

Analiza uzyskanych wyników pozwala sformułować podobny wniosek jak w przypadku poprzedniej kategorii, tj. najrzadziej żądania obywateli wobec władzy były prezentowane na łamach tabloidu „Fakt”, zaś najczęściej takie postulaty pojawiały się na łamach „Naszego Dziennika”. W tym kontekście warto zauważyć - posiłkując się jakościową analizą zawartości - że tytuł był nieprzychylny wobec władzy sprawowanej przez koalicję Platformy Obywatelskiej i Polskiego Stronnictwa Ludowego. Mogło to stanowić asumpt do tworzenia materiałów, które wyrażałyby niechęć czytelników do rządu, z wykorzystaniem żądań obywateli artykułowanych wobec ośrodka władzy. Nie należy jednak z tego wyciągać wniosku, że słabo wyakcentowane (lub ich brak) żądania obywateli wobec władzy na łamach „Faktu” (i innych gazet) oznaczały wspieranie koalicji rządowej przez ten tytuł.

Uwiarygodnienie lub poparcie dla dzialań lub żądań obywateli. Kolejne - istotne z punktu widzenia badania modelu służby obywatelskiej - było pytanie, czy dziennikarz jako autor materiału prasowego popiera i uwiarygodnia żądania oraz propozycje obywateli. Sprawdzano także, czy analizowany artykuł 
prezentuje w pozytywnym świetle żądania i propozycje obywateli. Dane zostały zamieszone w Tabeli $3^{18}$.

Tabela 3. Uwiarygodnienie lub poparcie dla działań lub żądań obywateli

\begin{tabular}{|c|c|c|c|}
\hline Tytul prasowy & Odpowiedź & $\begin{array}{c}\text { Częstość } \\
\text { (w liczbach) }\end{array}$ & $\begin{array}{c}\text { Procent odpowiedzi } \\
(\%)\end{array}$ \\
\hline \multirow{4}{*}{$\begin{array}{c}\text { „Gazeta } \\
\text { Wyborcza” }\end{array}$} & Nie & 32 & 9,3 \\
\hline & Tak & 39 & 11,4 \\
\hline & Nie dotyczy & 272 & 79,3 \\
\hline & Ogółem & 343 & 100,0 \\
\hline \multirow{4}{*}{ „Rzeczpospolita” } & Nie & 35 & 13,7 \\
\hline & Tak & 4 & 1,6 \\
\hline & Nie dotyczy & 216 & 84,7 \\
\hline & Ogółem & 255 & 100,0 \\
\hline \multirow{4}{*}{ „Fakt” } & $\mathrm{Nie}$ & 25 & 8,3 \\
\hline & Tak & 12 & 4,0 \\
\hline & Nie dotyczy & 266 & 87,8 \\
\hline & Ogółem & 303 & 100,0 \\
\hline \multirow{4}{*}{ „Nasz Dziennik” } & $\mathrm{Nie}$ & 31 & 13,5 \\
\hline & Tak & 53 & 23,0 \\
\hline & Nie dotyczy & 146 & 63,5 \\
\hline & Ogółem & 230 & 100,0 \\
\hline
\end{tabular}

Źródło: oprac. własne. Projekt „Journalistic Role Performance Around the Globe”.

Najwyższy poziom dziennikarskiego wsparcia i uwiarygodniania wobec działań i żądań obywateli odnotowano w „Naszym Dzienniku”. W 53 z 230 (23\%) tekstów poddanych analizie dziennikarze wyrażali wprost takie poparcie. $\mathrm{Z}$ jednej strony świadczy to o bliskim zawiązku autorów tekstów ze swoimi czy-

${ }^{18}$ W odróżnieniu od innych badanych kategorii, w niniejszej obok odpowiedzi „nie” i „tak” pojawiała się także odpowiedź „nie dotyczy”. Zgodnie z wytycznymi zawartymi w książce kodowej odpowiedź tę zaznaczano, gdy w którymś z poprzednich dwóch pytań zakodowano odpowiedź na „,nie”. 
telnikami, z drugiej zaś może budzić wątpliwości co do zachowania obiektywizmu i równowagi, szczególnie gdy teksty dotyczyły krytyki ówczesnej władzy, a dziennikarz opowiadał się po jednej ze stron.

Wpływ na społeczność lokalną. Analiza zawartości prasy prowadzona była także pod kątem tego, czy dziennikarskie teksty ukazywały wpływ określonego zdarzenia lub decyzji (np. w sferze polityki) na społeczność lokalną (miasta i regiony). Dane pochodzące z analizy ilościowej zostały zamieszczone w Tabeli 4.

Tabela 4. Wpływ na społeczność lokalną

\begin{tabular}{|c|c|c|c|}
\hline Tytul prasowy & Odpowiedź & $\begin{array}{c}\text { Częstość } \\
\text { (w liczbach) }\end{array}$ & $\begin{array}{c}\text { Procent odpowiedzi } \\
(\%)\end{array}$ \\
\hline \multirow{3}{*}{$\begin{array}{c}\text { „Gazeta } \\
\text { Wyborcza" }\end{array}$} & $\mathrm{Nie}$ & 324 & 94,5 \\
\hline & Tak & 19 & 5,5 \\
\hline & Ogółem & 343 & 100,0 \\
\hline \multirow{3}{*}{ „Rzeczpospolita” } & $\mathrm{Nie}$ & 237 & 92,9 \\
\hline & Tak & 18 & 7,1 \\
\hline & Ogółem & 255 & 100,0 \\
\hline \multirow{3}{*}{ „Fakt” } & Nie & 294 & 97,0 \\
\hline & Tak & 9 & 3,0 \\
\hline & Ogółem & 303 & 100,0 \\
\hline \multirow{3}{*}{ „Nasz Dziennik” } & $\mathrm{Nie}$ & 213 & 92,6 \\
\hline & Tak & 17 & 7,4 \\
\hline & Ogółem & 230 & 100,0 \\
\hline
\end{tabular}

Źródło: oprac. własne. Projekt „Journalistic Role Performance Around the Globe”.

W analizowanych tytułach nie stwierdzono, by artykuły zamieszczane na łamach badanej prasy - mającej charakter ogólnopolski - wywierały istotny wpływ na społeczności lokalne. Można sformułować ostrożny wniosek, że dziennikarze piszący o sprawach krajowych - np. politycznych - rzadko odwołują się w swojej narracji do tego, jakie może to przynieść konsekwencje konkretnym regionom i miastom. Nieco inaczej sytuacja wygląda w zakresie podejmowania przez dziennikarzy tematów gospodarczych. Tu zdecydowanie częściej pokazuje się wpływ decyzji ekonomicznych na kondycję regionów czy samorządów. 
Edukowanie w zakresie obowiązków i praw obywatelskich. W kolejnej kategorii próbowano odpowiedzieć na pytanie, czy analizowane materiały prasowe dostarczają wiedzy o obowiązkach lub prawach obywateli - szczególnie tych o zabarwieniu ekonomicznym, społecznym i politycznym. Dane w tym zakresie prezentuje Tabela 5 .

Tabela 5. Edukowanie w zakresie obowiązków i praw obywatelskich

\begin{tabular}{|c|c|c|c|}
\hline Tytul prasowy & Odpowiedź & $\begin{array}{c}\text { Częstość } \\
\text { (w liczbach) }\end{array}$ & $\begin{array}{c}\text { Procent odpowiedzi } \\
(\%)\end{array}$ \\
\hline \multirow{3}{*}{$\begin{array}{c}\text { „Gazeta } \\
\text { Wyborcza" }\end{array}$} & $\mathrm{Nie}$ & 319 & 93,0 \\
\hline & Tak & 24 & 7,0 \\
\hline & Ogółem & 343 & 100,0 \\
\hline \multirow{3}{*}{ „Rzeczpospolita” } & $\mathrm{Nie}$ & 246 & 96,5 \\
\hline & Tak & 9 & 3,5 \\
\hline & Ogółem & 255 & 100,0 \\
\hline \multirow{3}{*}{ „Fakt” } & Nie & 301 & 99,3 \\
\hline & Tak & 2 & 0,7 \\
\hline & Ogółem & 303 & 100.0 \\
\hline \multirow{3}{*}{ „Nasz Dziennik” } & $\mathrm{Nie}$ & 222 & 96,5 \\
\hline & Tak & 8 & 3,5 \\
\hline & Ogółem & 230 & 100,0 \\
\hline
\end{tabular}

Źródło: oprac. własne. Projekt „Journalistic Role Performance Around the Globe”.

Analiza zawartości wykazała, że dziennikarze badanych tytułów nie edukują obywateli w zakresie ich praw. Ciekawe wydaje się jednak pytanie, czy gdyby przeprowadzić ponowną analizę zawartości np. „Gazety Wyborczej” w odniesieniu do artykułów, które ukazały się na jej łamach po wyborach do Sejmu i Senatu w 2015 roku, to dałoby to inny obraz sytuacji w tym zakresie. Tytuł ten bowiem mocno angażuje się piórem swoich dziennikarzy w działania mające obronić w ich opinii zagrożoną demokrację w Polsce, edukując przy tym swoich czytelników i wskazując, jak ważna jest wolność mediów czy niezależność organów władzy sądowniczej.

Dostarczenie informacji dodatkowych - tła wydarzeń, informacji uzupełniających. Analizując zawartość prasy, zwracano również uwagę, czy dzien- 
nikarze dostarczają obywatelom informacji potrzebnych do podjęcia konkretnych decyzji, np. w zakresie działań politycznych (przy głosowaniu czy organizowaniu protestów). Badano również, czy dziennikarze informują o dotychczasowym działaniu podmiotów politycznych (np. jakie mają poglądy) i czy opisują motywy ich działania. Dane w tym zakresie zostały zawarte w Tabeli 6.

Tabela 6. Dostarczanie informacji dodatkowych - tła wydarzeń, informacji uzupełniających

\begin{tabular}{|c|c|c|c|}
\hline \multirow{2}{*}{ Tytuł prasowy } & Odpowiedź & $\begin{array}{c}\text { Częstość } \\
\text { (w liczbach) }\end{array}$ & $\begin{array}{c}\text { Procent odpowiedzi } \\
\text { (\%) }\end{array}$ \\
\hline \multirow{3}{*}{ Wyborcza” } & Nie & 338 & 98,5 \\
\cline { 2 - 4 } & Tak & 5 & 1,5 \\
\hline \multirow{3}{*}{ „Rzeczpospolita" } & Ogółem & 343 & 100,0 \\
\cline { 2 - 4 } & Nie & 218 & 85,5 \\
\cline { 2 - 4 } & Tak & 37 & 14,5 \\
\hline \multirow{2}{*}{ „Fakt” } & Ogółem & 255 & 100,0 \\
\cline { 2 - 4 } & Nie & 302 & 99,7 \\
\cline { 2 - 4 } & Tak & 1 & 0,3 \\
\hline \multirow{3}{*}{ „Nasz Dziennik" } & Ogółem & 303 & 100,0 \\
\cline { 2 - 4 } & Nie & 224 & 97,4 \\
\cline { 2 - 4 } & Tak & 6 & 2,6 \\
\hline
\end{tabular}

Źródto: oprac. własne. Projekt „Journalistic Role Performance Around the Globe”.

Najwyższy procent informacji uzupełniających odnotowano w dzienniku „Rzeczpospolita”, choć - co należy podkreślić - prawie 15-procentowy wynik także nie jest satysfakcjonujący z punktu widzenia realizacji modelu społecznej odpowiedzialności mediów. Można jednak założyć, że najczęściej tego typu informacje pojawiają się na łamach prasy - przede wszystkim opiniotwórczej w czasie kampanii wyborczych. Warto w tym kontekście przypomnieć, że analizowane teksty pochodziły z lat 2012-2013, zaś budzące najwięcej emocji wybory prezydenckie i parlamentarne w Polsce odbyły się w 2015 roku.

Pytania od obywateli. Kolejną badaną kwestią było pytanie o to, czy analizowane materiały dziennikarskie zawierały pytania od zwykłych obywateli 
skierowane do polityków sprawujących władzę. Koderzy zwracali uwagę na wprost wyrażone pytania lub ich opis dokonany przez dziennikarza w artykule prasowym. Danych ilościowych w tym zakresie dostarcza Tabela 7.

Tabela 7. Pytania od obywateli

\begin{tabular}{|c|c|c|c|}
\hline \multirow{2}{*}{ Tytuł prasowy } & Odpowiedź & $\begin{array}{c}\text { Częstość } \\
\text { (w liczbach) }\end{array}$ & $\begin{array}{c}\text { Procent odpowiedzi } \\
\text { (\%) }\end{array}$ \\
\hline \multirow{3}{*}{ Wyborcza" } & Nie & 342 & 99,7 \\
\cline { 2 - 4 } & Tak & 1 & 0,3 \\
\hline \multirow{3}{*}{,Rzeczpospolita” } & Ogółem & 343 & 100,0 \\
\cline { 2 - 4 } & Nie & 255 & 100,0 \\
\cline { 2 - 4 } & Tak & 0 & 0,0 \\
\hline \multirow{2}{*}{ „Fakt” } & Ogółem & 255 & 100,0 \\
\cline { 2 - 4 } & Tak & 301 & 99,3 \\
\cline { 2 - 4 } & Ogółem & 2 & 0,7 \\
\hline \multirow{2}{*}{ „Nasz Dziennik” } & Nie & 303 & 100,0 \\
\cline { 2 - 4 } & Tak & 227 & 98,7 \\
\cline { 2 - 4 } & Ogółem & 3 & 1,3 \\
\hline
\end{tabular}

Źródto: oprac. własne. Projekt „Journalistic Role Performance Around the Globe”.

$\mathrm{W}$ analizowanych artykułach - z małymi wyjątkami - nie znaleziono pytań od obywateli do władzy. Wspomniane wyjątki to łącznie 6 na 1130 badanych publikacji.

Informacje o działaniach podejmowanych przez obywateli. Analizując zawartość tytułów prasowych w perspektywie dziennikarskiego modelu służby obywatelskiej, zwracano uwagę, czy w materiałach prasowych zawarte są informacje o działaniach podejmowanych przez obywateli, takich jak: kampanie, akcje, protesty, obchody, demonstracje. Teksty dziennikarskie analizowano także pod kątem ewentualnego poinformowania czytelników, gdzie i kiedy takie akcje zostały zorganizowane, jaki był ich motyw przewodni, jaki miały skutek. Dane w tym zakresie przedstawione zostały w Tabeli nr 8 . 
Tabela 8. Informacje o działaniach podejmowanych przez obywateli

\begin{tabular}{|c|c|c|c|}
\hline Tytul prasowy & Odpowiedź & $\begin{array}{c}\text { Częstość } \\
\text { (w liczbach) }\end{array}$ & $\begin{array}{c}\text { Procent odpowiedzi } \\
\text { (\%) }\end{array}$ \\
\hline \multirow{3}{*}{$\begin{array}{c}\text { „Gazeta } \\
\text { Wyborcza” }\end{array}$} & Nie & 322 & 93,9 \\
\hline & Tak & 21 & 6,1 \\
\hline & Ogółem & 343 & 100,0 \\
\hline \multirow{3}{*}{ „Rzeczpospolita” } & Nie & 240 & 94,1 \\
\hline & Tak & 15 & 5,9 \\
\hline & Ogółem & 255 & 100,0 \\
\hline \multirow{3}{*}{ „Fakt” } & Nie & 300 & 99,0 \\
\hline & Tak & 3 & 1,0 \\
\hline & Ogółem & 303 & 100,0 \\
\hline \multirow{3}{*}{ „Nasz Dziennik” } & Nie & 187 & 81,3 \\
\hline & Tak & 43 & 18,7 \\
\hline & Ogółem & 230 & 100,0 \\
\hline
\end{tabular}

Źródło: oprac. własne. Projekt „Journalistic Role Performance Around the Globe”.

Analiza zawartości wykazała, że najwięcej informacji o aktywności obywatelskiej ukazało się na łamach „Naszego Dziennika”, zaś najmniej w tabloidowym „Fakcie”. O protestach i obchodach rocznic - w niewielkim stopniu - informowali także swoich czytelników dziennikarze „Gazety Wyborczej” i ,Rzeczpospolitej”.

Poparcie dla ruchów obywatelskich. W ostatniej poddanej analizie kategorii doszukiwano się wyrażanych przez dziennikarzy słów dla poparcia ruchów obywatelskich. Szczególną uwagę zwracano - w przypadku zaistnienia w materiale prasowym takiego poparcia - czy dziennikarz o podmiotach tych wyraża się pozytywnie oraz czy prezentuje je jako wzór do naśladowania dla innych. Dane ilościowe w tym zakresie umieszczono w Tabeli 9. 
Tabela 9. Poparcie dla ruchów obywatelskich

\begin{tabular}{|c|c|c|c|}
\hline Tytuł prasowy & Odpowiedź & $\begin{array}{c}\text { Częstość } \\
\text { (w liczbach) }\end{array}$ & $\begin{array}{c}\text { Procent odpowiedzi } \\
(\%)\end{array}$ \\
\hline \multirow{3}{*}{$\begin{array}{c}\text { „Gazeta } \\
\text { Wyborcza" }\end{array}$} & $\mathrm{Nie}$ & 342 & 99,7 \\
\hline & Tak & 1 & 0,3 \\
\hline & Ogółem & 343 & 100,0 \\
\hline \multirow{3}{*}{ „Rzeczpospolita” } & Nie & 252 & 98,8 \\
\hline & Tak & 3 & 1,2 \\
\hline & Ogółem & 255 & 100,0 \\
\hline \multirow{3}{*}{ „Fakt” } & Nie & 302 & 99,7 \\
\hline & Tak & 1 & 0,3 \\
\hline & Ogółem & 303 & 100,0 \\
\hline \multirow{3}{*}{ „Nasz Dziennik” } & Nie & 213 & 92,6 \\
\hline & Tak & 17 & 7,4 \\
\hline & Ogółem & 230 & 100,0 \\
\hline
\end{tabular}

Źródło: oprac. własne. Projekt „Journalistic Role Performance Around the Globe”.

Przeprowadzona analiza pokazuje, że na ogół dziennikarze nie wyrażali zainteresowania ruchami obywatelskimi, a tym samym nie popierali ich działań. Wyjątkiem w tym zakresie jest „Nasz Dziennik”, choć i tu liczba tekstów traktujących o takich ruchach jest niewielka (17 na 230 artykułów). Wydaje się, że w dobie budowania społeczeństwa obywatelskiego wspieranie oddolnych inicjatyw obywateli byłoby działaniem niezwykle ważnym, a rola mediów w tym zakresie znakomicie wpisywałaby się w model dziennikarstwa zorientowany na obywateli.

\section{Podsumowanie}

Analiza ilościowa polskich tytułów prasowych w perspektywie dziennikarskiego modelu służby obywatelskiej autorstwa Claudii Mellado dostarcza co najmniej kilka wniosków, które mogą stanowić asumpt do pogłębionych badań jakościowych i analiz porównawczych. Po pierwsze, warto podkreślić, że analizowane materiały dziennikarskie w niewielkim stopniu wpisują się w wy- 
żej wskazany model. Dziennikarze nie przywiązują wagi do wspierania określonych grup społecznych i promowania inicjatyw obywatelskich. Po drugie, z przytoczonych danych ilościowych wynika, że niedostatecznie upominają się $\mathrm{w}$ imieniu społeczeństwa o prawa obywateli oraz nie edukują ich w zakresie obowiązków i praw obywatelskich. Po trzecie, w niedostatecznym stopniu informują obywateli o dotychczasowym działaniu podmiotów politycznych i w ograniczonym zakresie analizują motywy ich działania, nie dostarczając tym samym obywatelom wiedzy niezbędnej do podjęcia określonych decyzji czy działań politycznych. Po czwarte, z przeprowadzonych badań ilościowych wynika, że najbliższy charakterystyce modelu dziennikarstwa zorientowanego na obywateli, sformułowanego przez Mellado, jest katolicki „Nasz Dziennik”, zaś najdalszy tabloidowy „Fakt”. Uwzględnić należy przy tym specyfikę wybranych tytułów, w tym ich orientację ideologiczną, a także kontekst społeczno-polityczny („Nasz Dziennik" reprezentuje bowiem pewną grupę społeczną, charakteryzującą się określonymi wartościami i preferencjami politycznymi, a jednocześnie pozostaje w opozycji do innych).

Ponadto, rozważając problem dziennikarstwa w ujęciu modelu służby obywatelskiej z perspektywy społecznej odpowiedzialności mediów, należy stwierdzić - biorąc pod uwagę otrzymane w badaniu dane - że dziennikarstwo takie można ostrożnie uznać za fasadowe, tj. media jako uczestnik życia publicznego deklarują działania na rzecz społeczeństwa i obywateli, w praktyce natomiast $\mathrm{w}$ niewielkim stopniu wypełniają zadania związanie z prezentowaniem głosu zwykłych obywateli czy promowaniem podejmowanych przez nich inicjatyw.

Dziennikarstwo zorientowane na obywateli z uwzględnieniem społecznej odpowiedzialności mediów może wydawać się w dzisiejszych czasach trudne do realizacji w praktyce. $Z$ jednej strony, media mają służyć obywatelom, stwarzać im równe szanse publicznego wyrażania swoich opinii i racji, z drugiej zaś, są one podporządkowane rozmaitym podmiotom, zjawiskom i zachowaniom rynkowym, co często utrudnia - a niekiedy nawet wyklucza - działanie w interesie jednostek, grup społecznych, narodu. W tym kontekście niebezpieczne są także widoczne w Polsce podziały polityczne, które przekładają się już na polaryzację nie tylko sceny politycznej, ale również społeczeństwa i mediów. W warunkach konfliktu i sporu zadecydowanie trudniej w pełni realizować zadania wynikające ze społecznej odpowiedzialności mediów.

\section{Bibliografia}

Culbertson H., Three perspectives in American journalism, „Journalism Monographs” 1983, No. 83, pp. 1-33.

Dobek-Ostrowska B., Barczyszyn P., Michel A., Zmiana w dziennikarstwie. Kultura zawodowa polskich dziennikarzy (badania ilościowe), „Studia Medioznawcze” 2013, nr 1, s. 11-28. 
Goban-Klas T., Media i komunikowanie masowe. Teorie i analizy prasy, radia, telewizji i Interne$t u$, Wydawnictwo Naukowe PWN, Warszawa 2008.

Hanitzsch T., Deconstructing Journalism Culture. Toward a Universal Theory, „Communication Theory" 2007, No. 4, pp. 367-385.

Jęczeń J., Zielińska-Król K., Koncepcja odpowiedzialności mass mediów w myśli Denisa McQuaila, „Roczniki Nauk o Rodzinie i Pracy Socjalnej” 2012, nr 4, s. 285-298.

Kapuściński R., Dwa światy, „Newsweek Polska” 2001, nr 16-17, s. 166.

Kononiuk T., Profesjonalizacja $w$ dziennikarstwie. Między modernizmem a ponowoczesnościa, Oficyna Wydawnicza ASPRA-JR, Warszawa 2013.

Lasswell H., The Structure and Function of Communication in Society, [in:] The Communication of Ideas, ed. L. Bryson, Harper, New York 1948.

Lazarsfeld P., Merton R., Mass Communication, Popular Taste, and Organized Social Action, [in:] The Communication of Ideas, ed. L. Bryson, Harper, New York 1948.

McQuail D., Teoria komunikowania masowego, przeł. M. Bucholc, A. Szulżycka, Wydawnictwo Naukowe PWN, Warszawa 2008.

Mellado C., Professional roles in news content: Six dimensions of journalistic role performance, „Journalism Studies” 2015, No. 4, pp. 596-614.

Nieć M., Komunikowanie społeczne i media. Perspektywa politologiczna, Wolters Kluwer Polska Sp. z o.o., Warszawa 2010.

Nowakowski K., Spoteczna odpowiedzialność mediów w systemie gospodarki wolnorynkowej, Szkoła Wyższa im. Bogdana Jańskiego, Warszawa 2009.

Secler B., Polityka i media w obliczu demokracji medialnej, [w:] Demokracja w obliczu nowych mediów. Elektroniczna demokracja, wybory przez Internet, kampania w sieci, red. M. Musiał-Karg, Wydawnictwo Adam Marszałek, Toruń 2013.

Stankiewicz W., Media a demokracja w społeczeństwie informacyjnym, [w:] Teoria i praktyka funkcjonowania mediów, red. J. Marszałek-Kawa, Wydawnictwo Adam Marszałek, Toruń 2010.

Stępińska A., Ossowski S., Dziennikarze w Polsce: wartości, priorytety i standardy zawodowe, „Studia Medioznawcze” 2011, nr 1, s. 17-30.

Stępińska A., Ossowski S., Pokrzycka L., Nowak J., The Journalists and Journalism of Poland, [in:] The Global Journalist in the $21^{\text {st }}$ Century, ed. D.H. Weaver, L. Willnat, Routledge, New York and London 2012.

Stępińska A., Ossowski S., Three Generations of Polish Journalists: Professional Roles and Identities, „Journalism Studies” 2012, No. 5-6, pp. 857-867.

Weaver David H., Wilhoit Cleveland G., The American Journalist in the 1990s: U.S. News People at the End of an Era, Lawrence Erlbaum Asssociaties, Mahwah NJ 1996. 
Bartłomiej Secler, Agnieszka Stępińska, Ewa Jurga-Wosik

Dominika Narożna, Kinga Adamczewska

\section{A citizen-oriented model of journalism from the point of view of paradigm of the social responsibility of the media. The press in Poland}

\section{(Summary)}

This paper aims to present a theoretically-empirical reflection on the citizen-oriented model of journalism developed from the social responsibility of the media paradigm. The main indicator of that model is the significant attention paid by journalists to the current perspective of the citizens (in terms of their expectations, demands, actions), to educate citizens about their rights and obligations, as well as to encourage people to actively participate in public debate. The study was conducted under the framework of the international comparative project "Journalistic Role Performance Around the Globe", launched and coordinated by C. Mellado and L. Hellmueller from Texas State University, USA (www.journalisticperformance.org). The results of empirical research (an analysis of the contents of four Polish daily newspapers) revealed that Polish journalism insufficiently incorporates the model of civic service, one of whose most rudimentary aims is the support, education and representation of the citizens' interests.

Keywords: journalism; models of journalism; Polish journalists; press in Poland; social responsibility of media. 